\title{
The Higher Theological Education in the Romanian Orthodox Church after 1990 - pastoral necessity and missionary responsibility
}

\section{Ion VICOVAN*}

\section{Historical references of the theological education}

As we all well know from the sermons of the two Saint Apostles, Andrew, ,the first one to be called” (John 1, 40) and Philip, ,from the town of Andrew and Peter” (John 1,44), Romanian Christianity has an apostolic origin ${ }^{1}$.

From its very beginning, the Diocese of Tomis, the first administrative church structure, had hierarchs who were participants to the ecumenical and local sinodes, well prepared from a theological point of view, and who became remarkable through their lives, works and Orthodoxy. The Minor Scythia is also the place where the well known theologians, Saint John Cassian and Saint Dionysios the Humble, were born and formed, at least for a while, along with other Scythian monks, who have become acknowledged and renowned for their theological education ${ }^{2}$.

* PhD, Rev., Professor, Faculty of Orthodox Teology at „Al. I. Cuza” University from Iasi.

${ }^{1}$ See the study of Prof. Dr. Emilian Popescu, Early Christianity on Romania's Territory, in the vol. „Watching and Working for Salvation”, Iași, Trinitas Pub., 2000, pp. 194-215.

${ }^{2}$ Pr. Prof. Dr. Ioan G. Coman, Church Writers from the Pre-Romanian Period, EIBMBOR, București, 1979, pp. 20-34. 
In the first half of the first millenium, as well as in the first half of the second one, inclusively until the end of the XVIIIth century and the beginning of the XIXth one, our Church had theologically well prepared hierarchs and priests, believers and pious people who passed on without change the teachings of the Gospels, who guided their spiritual sons towards salvation and defended the righteous faith against the Catholic and Protestant (Calvinist) proselytism. All these happened despite the fact that the Church had not founded any special schools for the preparation of the cleriks, or at least they are not known today.

Along with the education received in the parental home, in the case of the sons of priests, those who aspired to be ordained would train in monasteries, in the Metropolitan schools, in the schools of the Dioceses, and those ascribed to certain churches (like St. George - the Old, Colțea, Văcărești, Lady Bălașa, etc).

Within the lordly academies, among the studied subjects, theology occupied a place of honnor ${ }^{3}$. In the XVIIIth century, the first attempts to establish special schools for the training of future priests are recorded ${ }^{4}$. A superior theological school came into being at Putna Monastery in the year 1774, based on the model of the one in Kiev, thanks to the two great Moldavian cultural personalities: Metropolitan Iacob Putneanul and Archimandrite Vartolomeu Măzăreanul ${ }^{5}$.

3 Pr. Prof. Dr. Mircea Păcurariu, The History of the Romanian Orthodox Church, vol. II, Trinitas Pub., Iași, 2006, p. 23.

${ }^{4}$ In 1784 Ștefan Racoviță of The Romanian Country founded a school ascribed to St Demetrios church in Craiova, in which the candidates for priesthood were to be taught; in Moldavia, Constantin Mavrocordat organised, in 1741, 40 day courses at the diocesan residences, which were attended by the newly ordained priests et al (cf Pr. Prof. Dr. Mircea Pacurariu, The History of the Romanian Orthodox Church, vol. III, Trinitas Pub., Iași, 2008, p. 218).

${ }^{5}$ Pr. Prof. Dr. Mircea Păcurariu, The History of the Romanian Orthodox Church, vol. III, p. 218. 
Later on, enlightened hierarchs of our Church laid the foundation of the very first theological schools. We mention thus the school for the training of priests founded at the end of the XVIIIth century (1797) by the learned Joseph, the first Bishop of Argeș, near Antim Monastery.

Also in Transylvania, in the year 1786, Dimitrie Eustatievici, the principal of the Orthodox Romanian schools, opened at Sibiu "The norm course", a training course of future teachers, within which candidates for priesthood were also educated ${ }^{6}$. In the year 1811, Bishop Vasile Moga (1810-1845) reorganised the clerical course, beginning ,A systematic training course for the Orthodox clergy", with a study duration of six months, which was lead by Gheorghe Lazăr. He taught at Sibiu for three years, courses of Dogmatics, Ethics, Church Singing and the Typikon?

Shortly after, ,the enlightener of Moldavia”, Metropolitan Veniamin Costachi (1803-1842) laid the foundation of the first seminar in Wallachia, later called "Seminaria Veniamina”, near Socola Monastery, becoming over the time, according to Constantin Erbiceanu's statement, „The Sorbonne of the Romanians"

Over the passing of time, other seminars appeared within the Metropolitan churches in Moldavia and Wallachia. They appeared as a pastoral necessity, but also as a consequence of the application of a clause in the Organic Regulations, between the years 1836 and 1837. In 1852, the courses of the Seminar in Huși

${ }^{6}$ Univ. Prof. Dr. Paul Brusanowski, The Faculty of Theology „Andrei Șaguna” Sibiu-Monograph, in the vol. „Vocation and giving. Orthodox theological education in Sibiu, 230 years of history in faces and icons", Andreiana Pub., Sibiu, 2016, p. 39.

${ }^{7}$ Univ. Prof. Dr. Paul Brusanowski, The Faculty of Theology „Andrei S,aguna” Sibiu-Monograph, p. 39.

${ }^{8}$ C. Erbiceanu, The History of Veniamin Seminary of Socola Monastery, founded in 1804, Iași, 1885, p. 122. 
were opened, and also in Wallachia those of the Seminar in Bucharest, named Central, in 1836. In the same year, there was also established the Seminar in Buzău, and a year later, in 1837, the foundation was laid for the one in Râmnicu Vâlcea. To the above mentioned seminars (București, Iași, Râmnic, Buzău, Argeș, Roman and Huși) one may also add the one in Ismail, moved in 1878 in Galaţi, and, since 1872, The Metropolitan Nifon Seminar in Bucharest ${ }^{9}$.

In Transylvania, even since 1846, Andrei Şaguna has decided to expand the existing courses from the time of Vasile Moga from six months to a year, then (1852) to two years, and, since 1861 , to three years. Thus they they stayed utill the year $1921^{10}$. In the areas of Arad and Timișoara, theology courses were initiated also near the end of the XVIIIth century ${ }^{11}$.

In the second half of the XIXth century the first faculties of theology in the country came into being, along with the founding of the universities. Thus, in 1860, the Faculty of Theology in Iași is born, being a co-founder of „Al. I. Cuza” University, the one in Bucharest entering history in $1881^{12}$. We also mention the fact that, in 1875, the Faculty of Theology in Cernăuţi appeared,

9 Pr. Prof. Dr. Mircea Păcurariu, The History of the Romanian Orthodox Church, vol. III, pp. 221-225.

10 Univ. Prof. Dr. Paul Brusanowski, The Faculty of Theology „Andrei Șaguna" Sibiu-Monograph, pp. 40-41.

${ }^{11}$ The psalm reader Mihail Martinovici in Timișoara opened, in 1790-1794, a „priesthood course”. In the year 1822 theology courses were started in Arad, with a duration of two years, which, starting from 1825, expanded their duration to three years of study (as they remained until 1918 (cf. Pr.Prof. Dr. Mircea Păcurariu, The History of the Romanian Orthodox Church, vol. III, p. 237)

12 Pr.Prof. Dr. Mircea Păcurariu, The History of the Romanian Orthodox Church, vol. III, p. 226-227. 
within The Fenacesco-Iosefine University ${ }^{13}$; it was one of the best faculties of theology of its time and, certainly, the best Romanian faculty of theology in that period, the courses being held in German.

We also mention that, in the modern age, ,the laicisation of education was a constant desire, emphasised towards the end of the XIXth century through the Minister Vasile Conta's project ${ }^{14}$, which represents the first attempt to remove religion from the school programmes". Conta is also the one who closed the confessional schools, a process that gained weight during the reign of Al. I. Cuza and ,had gotten the population and the church authorities used to the limitation of this educational segment, which, in 1880, was represented by the lower seminars, the higher seminars and the faculty of theology", all depending on the state ${ }^{15}$.

After Romania's union, apart from the old seminars (Central and Nifon in Bucharest, Veniamin in Iași, those in Râmnic, Buzău, Argeș, Roman, Huși and Galați, Chișinău and Ismail in Basarabia), other new ones appeared in Craiova, Constanța, Câmpulung (Argeș, for the war orphans), Dorohoi, Pomârla (both in the Botoșani county) and a monastic seminar

13 Pr. Prof. Dr. Mircea Păcurariu, The History of the Romanian Orthodox Church, vol. III, Iaşi, p. 230.

${ }^{14}$ We mention also the fact, not without importance, that Vasile Conta was a priest's son, but his father, ,at that time, had an interdiction from the Metropolitan consistory in Iasi to practice his profession" (Nicolae Isar and Cristina Gudin, From the history of the Romanian school policy. Education problems in the Parliament debates (1864-1899), Bucharest University Pub., 2004, p. 117).

${ }^{15}$ Nicolae Isar and Cristina Gudin, From the History of the Romanian School Policy. Education Problems in the Parliament Debates (1864-1899), Bucharest University Pub., 2004, p. 123. 
established in Neamt, later moved to Cernica, all of them with an ephemeral existence ${ }^{16}$.

In what regards the higher education, we mention that, at the Faculty of Theology in Cernăuți, the courses were held in Romanian after 1918. In 1926 a faculty of theology was established at Chișinău, within the University in Iași, and it merged, in 1941, with the one in Bucharest. The one in Cernăuți moved to Suceava in 1919 and it would merge with the one in Bucharest in $1948^{17}$. We also mention that all these institutions of higher theological education were under the leadership and guidance of the state.

In Transylvania and Banat, the old theological institutuions of Sibiu, Arad and Caransebeș were lifted to the rank of Theological Academies, with four years of study, under the direct guidance of the Church. To theses ones two new theological Academies were added (Oradea, 1923 and Cluj, 1924). The attempts of the Transylvanian hierarchs for these Academies to receive the right of issuing Bachelor's degrees were unsuccessful. Only the one in Sibiu was granted this right in the year 1923, after the many and persistent endevours of Metropolitan Nicolae Bălan (1920-1955) ${ }^{18}$.

It is to be reminded that, in the year 1927, a synodal commission, headed by Metropolitan Nicolae Bălan, presented the Holy Synod with a bill, according to which all theological education institutions were to be placed under the leadership of the Church. Three types of theological schools were proposed:

16 Pr. Prof. Dr. Mircea Păcurariu, The History of the Romanian Orthodox Church, vol. III, p. 400.

17 Pr. Lect. Dr. Mihai Vizitiu, Virginia Popa, The History of Higher Theological Education in Moldavia and Bukovina, in „TV”, no. 1-6/ 2007, Iași, pp. 78-90.

18 Pr. Prof. Dr. Mircea Păcurariu, The History of the Romanian Orthodox Church, vol. III, p. 400. 
four year Faculties of Theology, Theological Academies, also with four years, and Vocational Seminars with six classes (of a transient nature, in which they meant to receive graduates of four secondary classes). Because of the opposition, especially of the professors from the Faculties of Theology, this project was not approved ${ }^{19}$.

In 1948, due to ,the Law for the General Organisation of the Cults", theological schools of all degrees passed under the care of the respective cult, under the control of the Ministry/Department of Cults. After this happened, theological schools suffered also a significant reorganisation, in the sense that they were drastically reduced, being separated into Schools for church singers, Theological Seminars (six in number) and Theological Institutes of a academic degree (Bucharest, Sibiu, Cluj, the last one merging, in 1952, with the one in Sibiu).

\section{Theology Schools after 1990 - pastoral necessity and missionary responsibility}

We can easily see that all the different types of theological schools mentioned above, established over many centuries, are the result of a pastoral necessity and of a missionary responsibility.

Pastoral necessity, because the faithful people needed theologicaly trained shepherds, to ,teach them the word of the Truth", to place "God's commandments" and ,the words of eternal life" (Ioan 6,68) by their hearts, to impart with them the sanctifying grace and to guide them on the road towards salvation.

19 Pr. Prof. Dr. Mircea Păcurariu, The History of the Romanian Orthodox Church, vol. III, p. 401-402. 
Missionary responsability, because both in Moldavia, as well as in Wallachia to a lesser extent, but especially inTransylvania to a greater extent, the priest was called upon to defend the righteous faith against Catholic and Calvinistic proselytism actions.

After 1990, the former theological institutions, along with the reestablished or newly established faculties, were incorporated in the Universities. Likewise, the former Theological Academies in Transylvania were restored as faculties or departments, in the same way as new faculties/departments appeared in other cities, their number rising to 15 , having one or more specialisation (Pastoral Theology, Didactic Theology, Social Work Theology and Sacred Art Theology).

As it had been the case before 1989, also immediately after this year, the same pastoral necessity can be noticed, maybe even an increased one, and a greater missionary responsibility. Why an increased pastoral necessity? Because until the year 1989 there were many parishes and many filial churches attended by a reduced number of priests. And this was happening because of the small number of seminar graduates who could be ordained, as well as of those with higher theological studies. When comparing with previous centuries, during which we could encounter a significant number of priests and deacons in every village ${ }^{20}$, now

20 According to Pr. Academician Mircea Păcurariu, in the XVII-th century and the beginning of the XVIII-th one, ,almost in every village there were severel priests and deacons" (The History of the Romanian Orthodox Church, vol. II, Iași: Trinitas Pub., 2006, p. 212). Also in the XVIII-th century ,the number of priests continued to be very high". For instance, at the beginning of the XIX-th century, in the two churches in Sămara-Argeș there were 5 priests and 16 deacons. From a census of the priests in the priests within the Metropolitan church in Wallachia, done in 1810, in the Stănislăvești-Vlașca, with 11 houses, there were 2 priests, 5 deacons and 3 psalm readers (p. 498). In Moldavia, we find out from the statistics, arranged by the Exarch-Metropolitan Gavriil Bănulescu Bodoni, that there were 2313 churches, with a number of 45 archbishops, 4229 priests and 733 deacons (p. 498). 
the process is almost reversed, in many situations a priest having in his care 3-4 parishes/ filial churches in his care.

For the image to be complete, we need to specify that, while in the distant past the number of believers within a parish was quite small, the villages having a small number of families, in the time period up to 1989 their number became very high. This was also because of the administrative and territorial reorganisation of Romania (1968), as well as the population increse as a result of the enforcement of the anti-abortion law.

Coming back, after 1989, as a result of obtaining freedom, the Church reorganised and diversified its complex work, including the work referring to theological education, both the lower and the higher one, as we have mentioned above. Now pastoral necessity, like missionary responsability has been imposed more acutely than before. And this has been motivated by the following realities:

- the great number of parishes, respectively of filial churches attended by a reduced number of serving priests;

- the transformation of many filial churches, of most of them, into parishes;

- the increase of the number of churches and chapels built after 1989, this including also the monasteries and the hermitages, al of them needing an increased number of clergymen with theological studies;

- the founding of new parishes. For example, in the Archdiocese of Iaşi, and in the Mitropolitan Church of Moldavia and Bucovina respectively, the pastoral-missionary programme „no village without a church" was implemented, programme initiated and enforced by the His Beatitude Father Daniel, Patriarch of the Romanian Orthodox Church, then the Metropolitan of Moldavia and Bucovina;

- proselytism, most often very aggressive, coming from the neo-protestant cults in an attempt to "make new disciples" and 
„evangelisations” with the purpose to infiltrate, as much as possible, in every community (Orthodox/mostly Orthodox); - the integration of the Theology Faculties into Universities, forced them to the increase of the academic quality, on the one hand, but also of spirituality, of Christian testimony, on the other hand;

- the intensifying and diversifying of the Church's work also lead to creating new specializations within the Faculties of Theology. Practicaly, with the opportunity to teach the subject of Religion in the schools of the public system led to the creation of the specialisation called Didactic Theology, the establishment of social and philanthropic settlements led to the introduction of the Social Work Theology specialization, and for the restoration and preservation of the national patrimony (which is $80 \%$ ecclesiastical), there was established the specialisation Cultural Patrimony, later becoming Sacred Art;

- the emergence of new challenges (new religious movements, the increase in the number of people who declare themselves atheists or of associations of the "secular humanist" kind, which manifest themselves strongly and openly against the Church and so on);

- the new context in which the Church operates, in the sense that, until 1989, it had been somewhat isolated and marginalised, but after 1990, the Church came back into the life of the people. It is put alongside other institutions and in a dialogue with them. The theologian student, as well as the institution that used to form him, is no longer isolated from society, both him and the forming institution (the faculty) are inside society, right in its view.

Taking into account the considerations listed above, to which others can be added, we draw the esential conclusion that theology, as ,function of the Church" that ,serves the Church, the 
people of God, for which it exists as well" ${ }^{21}$ „must be situated in the sense and the direction given by the Church's general work, which is concerned with one fundamental thing: man's salvation" 22 . And so we find that the two dimensions or coordinates of theology -pastoral necessity and missionary responsibility - are as valid today as they have been before. More so, after 1990 they have acquired a stronger accent.

They have been underlined in an admirable way by His Beatitude Father Daniel, The Patriarch of the Romanian Orthodox Church, at that time the Metropolitan of Moldavia and Bucovina, on the 12th of June 1991, with the occasion of the integration of the Faculty of Theology in Iași within the „Alexandru Ioan Cuza" University. His Beatitude stated then something which is valid even today, namely that an essential dimension of theology is the pastoral one, in the sense that it „must respond to the urgent needs of the Church, to be a thology of the times we are living in, the same way the theology of the Holly Fathers responded to the immediate needs of the Church. To be a priest of your time is not only an incentive, but also a requirement always imposed by the redempting serving of the Church in different contexts and times...Theology must respond to the problems of our times, to today's need of salvation and sanctification. Theology within its pastoral dimension means to spiritually feed man taking into account the spiritual hunger and thirst of today, the sufferings and the concrete problems of the present day. A pastoral theology applies the principles of faith, taking into account concrete, diverse and new people and

${ }^{21}$ Pr. Honoured Prof. Dr. Gheorghe Metallinos, The Theologian in the Service of Church, in the vol. ,The Academic Theology and Its Responsibility in the Church Mission", Iași: Doxologia Pub., 2016, p. 96.

22 Pr. Prof. Dr. Ștefan Buchiu, The Mission of the Orthodox Theology Faculties in the Contemporary Context, in the vol. ,The Academic Theology and Its Responsibility in the Church Mission”, p. 106. 
situations.... Theology is pastoral when it expresses itself as a holy duty for the life and the salvation of every man"23.

Alongside the pastoral dimension theology has, acoording to the vision of the same great theologian and hierarch of our Church, also a missionary dimension. On the same occasion mentioned above, the Patriarch Father Daniel showed that ,theology seen through its missionary dimension means for us, first and foremost, the care to convey the faith and love of Jesus to the young generations or the adults who have forgotten Him. Throughout our lives we must strive to follow and receive Him more intensely in our lives. Modern secularisation also manifests as a weakening of faith and of spiritual life, of prayer. Many of the people today have forgotten the prayer or have lost it's rhythmic practice. Many of them are not faithless, but pray very little or do not pray at all. They do not deny the existence of God, but have fogotten or do not know how to find Him through prayer. Therefore theology must help people feel that God loves them. Theology is called upon to help each and every human being, who wears the appearance of God, to discover the possibilities of dialogue and communication with The One Whose appearance they wear, but also with their fellow humans...Theology in it's missionary dimension is the science charged with healing the souls sick with alienation and mistrust, of the lack of experinceing the presence of God in their daily life, sick with the alienation of ourselves. Theology is thus the science of healing isolation by promoting love and brotherly assistance which are derived from faith" 24 .

A special component of the missionary dimension is, in the vision of Father Patriarch Daniel, ,the openness towards the

${ }^{23}$ Gheorghe Popa, Virginia Popa, The Chronicle of an Institution with a Profound Edifying Vocation, in „Theological Writings”, Filaret Scriban Stavropoleos, Iasi: „Al. Ioan Cuza” University Pub., 2010, p. 45.

${ }^{24}$ Pr. As. Gheorghe Popa, A Long Waited Moment: The Opening of the Courses at the Theological Institute in Iasi, in T.V. no. 5-6/ 1990, pp. 124-125. 
universal", the only way ,that it can bring something constructive for the West and for the other Christian Churches". This, however, under one condition: through , the deepening and the validation of our gifts and the promoting of the dialogue between culture and faith". At this point, Father Patriarch compares theology with an oak whose large supporting branches match its roots, deeply thrust into the earth: „Likewise our Orthodox theology will open towards the great problems that trouble Christianity today, only to the extent in which it will seriously consider the devotion and prayer of our people, its Christian tradition of almost two thousand years" 25 .

However, the theology of today must answer not only the problems that Christianity faces, but also the problems that man must face: ,the progressive movements in all the fields, in literature and art through the appearance of realism, in philosophy through the autonomous thinking to nihilism, in physics and biology through the outburst that the evolutionary theories have gotten, as well as through their perspective on the cosmos" 26 .

According to the vision of His Beatitude Father Patriarch Daniel, theolgy must and has to meet the above mentioned challenges through the deepening and cultivation of the following directions:

-a. the study of the origin and evolution of secularism in Europe, with a critical and self-critical discernment on behalf of the Churches;

-b. the fostering of new relations between science and faith by going from divergence and confrontation to convergence and cooperation, thereby surpassing the exclusive dichotomy

25 Gheorghe Popa, Virginia Popa, The Chronicle of an Institution with a Profound Edifying Vocation, p. 46.

${ }^{26}$ Pr. Prof. Dr. Ștefan Buchiu, The Mission of the Orthodox Theology Faculties in the Contemporary Context, p. 112. 
between scientific research and spiritual life, between the desk and the altar;

-c. the dialogue of the academic theology with the secularised and pluralistic society, with all its freedom, must not diminish the freedom and the dignity of theology of being prayerful and confessing;

-d. in the face of civic individualism, what must be promoted are the theology of the person in communion, the holy gift of life, human dignity and solidarity with the lonely ones, maintaining a relationship between spiritual and social life, the mystical theology and the external mission of the Church;

-e. in the face of rationalist or syncretistic religious sectarianism, academic theology with a missionary and social impact must promote an authentic Christian life where the idea of holiness implies a total commitment, through prayer and action in living the Gospels of Jesus Christ;

-f. in the face of the phenomenon of globalisation, academic theology must be critical and creative, capable to discern between the positive and the negative, between the human and the inhuman ${ }^{27}$.

Also, starting from Andre Malraux's saying that „the XXI century will either be religious or it will not be at all", today's (Orthodox) theology must show what is the true religion and the true living and saving theology, especially in a more and more secularised world, in which God does not have a place in creation, and man becomes the slave of his own being's irational drives. In that regard, Academician Priest Dumitru Popescu states: „the Orthodox culture and spirituality considers that man's secret does

${ }^{27}$ Metropolitan Daniel, The Mission of the Orthodox Theology Faculties in the Contemporary Context, in „The Canle of Moldavia”, year XV (2006), no.67. pp. 30-33 at Pr. Prof. Dr. Ștefan Buchiu, The Mission of the Orthodox Theology Faculties in the Contemporary Context, p. 113. 
not reside in himself, but in God, as one that is created by God's image. That is why, man can only find fulfilment only to the extent in which he keeps the connection with his Archetype....The same way that the truth of an icon is not in and of itself, but in the person it represents, the same way the truth of man resides in his Model, that is in his divine Archetype" 28 .

Fllowing the same idea, Priest Dumitru Popescu also shows what the consequences upon the world are in this situation, where man, distancing himself from God, takes His place: „From the moment that man takes God's place on Earth, and considers himself the absolute master of the world, forgetting that it has not been he who created the world, he seeks to mold it at will" 29 . And in this case, on the one hand, the entire creation in general (mannature), and especially man, can no longer fulfil the purpose they have been created for; on the other hand, nature no longer recognises man as its master, as a result of the fact that man no longer recognises God as his Master.

Simultaneously, the same great theologian points out that ,the split between the public and the private, which has been discussed more and more often in recent times, and which has alienated religion from the objective sphere of society only to isolate it within human subjectivity, has also extremely damaging effects... the Christian unity of the Church is undermined and the foundations for a never-ending sectarian proliferation are laid, which pulverises Christianity in as many Christian denominations, which are not able to find their unity.... If we take into account the role that the Church has played in the history of our nation by maintaining its spiritual and moral unity, in spite of the hostility of a tumultuous history, but also the role the Church must have today for the spiritual and moral

28 Dumitru Popescu, Orthodoxy and Contemporaneousness, București: Diogene Pub., 1996, p.172.

${ }^{29}$ Dumitru Popescu, Orthodoxy and Contemporaneousness, p. 175. 
rebirth of the nation (italics added), after decades of atheist and comunist ideology, we can see the danger that the sectarian phenomenon represents for the unity of the Romanians" ${ }^{\text {"30 }}$.

The Greek professor Metallinos makes similar statements: „In a world which subdues truth to utility, knowledge to technique, logic to historical necessity, and fights within the limits of life and death, the Church and its theology are called to express their word about the hope in us (I Peter 3,15), to give meaning to human existence and to fill its distressing gaps, offering genuine freedom within the posibilities of ascetic selfovercoming and selfless love" 31 .

Similar and current incentives were given many decades ago by Professor Dumitru Stăniloae. The great Professor had in mind both the content of theology, with respect to its subject matters, and the quality of the professors. Regarding the content of theological education, the Priest Professor stated: „We must (emphasis mine) develop within our theologic education those concerns that can make Christian truth obvious to the man of today, who has walked the road of the science and the philosophy of the last few centuries. We need a lot of philosophy and Christian apologetics, we need a strong movement of Christian thinking to clarify and build the Christian Truth, in the light and in the face of the new forms of thinking, of the new progresses of science. How good would it be if the Church had around twenty representatives of a Christian philosophy and if the whole priesthood rose to such a level so as to meet the expectations of today's intelectual man! Theologic education must receive new development and apropiate conditions for this" ${ }^{\prime 2}$.

${ }^{30}$ Dumitru Popescu, Orthodoxy and Contemporaneousness, p. 174.

${ }^{31}$ Pr. Honoured Prof. Dr. Gheorghe Metallinos, The Theologian in the Service of the Church, p. 103.

32 D. Stăniloae, Orthodoxy and Contemporaneousness, in The Romanian Telegraph, Year XC, no. 39, 27 Sept. 1942, in op. cit.,III, p. 281. 
Furthermore, in what regards the quality and purpose of the theology professors, the same great Professor said that ,the great art, the big problem for the theology professors...is the awakening and the intensification of spiritual life in the young people. And spiritual life means life dominated in all its moments and actions by the thinking of God. When God becomes the never-failing Master, forever believed present, waching you and judging you, you have firmly and without return taken the path towards a spiritual life" ${ }^{\prime 3}$.

The Greek Professor quoted above (Metallinos) expresses himself in similar words: „one cannot understand science and theologic education without the awareness of the fact that the Orthodox man of science does not cease to be a member of the Church at his working place, carrying out his work in his own way for the building of the church body. When this awareness is weakened, then the theologian-man of science, even though he can distinguish himself as an authority in the field of science, through amzing accomplishments in the field of philology, of philosophy, of history or archeology, he is not, however, a theologian of the Church"34.

\section{Instead of conclusions}

Not long ago (in 2008), Academician Priest Mircea Păcurariu stated that, in the time span of over 15 functioning years for the Faculties of Theology, respectively for the Departments of Theology, ,it has been proven that many things are not necessary, that they do not have appropriate teaching

33 Dr. D. Stăniloae, For a Better Education in the Theology Schools, in The Romanian Telegraph, year LXXXIV, no. 38, Sept. 13, 1936, in op. cit., p. 868.

${ }^{34}$ Pr. Honoured Prof. Dr. Gheorghe Metallinos, Teologul în slujirea Bisericii, p. 97. 
staff, nor speciality libraries"35. Therefore, starting from the title of the present essay, we naturally ask ourselves a few questions, to which I launch the invitation that we should answer together or that each Faculty should answer individually:

- Do the Faculties / Departments of Theology of today represent a pastoral necessity? If yes, to what extent?

- Do the Faculties / Departments of Theology train missionary students for the Church, regardless of the place or method in which they would serve it?

- Is our theologic scientific work doubled by a spiritual one, knowing that ,no matter how high and imposing it may be, it does not initiate in the spiritual experience, but it assumes it"?

- starting from the conviction that ,the more ecclesiastical theological education is, which is offered in an education institution, the more it maintains and facilitates the acces to the Church life" ${ }^{36}$, we ask ourselves the question weather the usually great number of graduates and their insufficient theological missionary training could rather be an additional problem for the Church, instead of being a contribution for its better state? Do we not contemplate the risk that they, the graduates, instead of becoming loyal missionaries of the Church, should become its enemies?

Therefore, I personaly believe that the meeting at Alba Iulia forces us to reflect upon the fulfillment of the purpose of our Faculties / Departments of Theology in the service of the Church and the people.

${ }^{35}$ Pr.Prof. Dr. Mircea Păcurariu, The Theologian in the Service of the Church, vol. III, p. 474.

${ }^{36}$ Pr. Honoured Prof. Dr. Gheorghe Metallinos, The Theologian in the Service of the Church, p. 98. 